\title{
What Prompted Shadow Banking in China? Wealth Management Products and Regulatory Arbitrage
}

\author{
Syed Mehmood Raza SHAH ${ }^{1}$, Jianjun $\mathrm{LI}^{2}$, Qiang FU ${ }^{3}$
}

Received: September 01, 2020 Revised: October 26, 2020 Accepted: November 05, 2020

\begin{abstract}
Shadow banking in China has been growing rapidly; banks use wealth management products aggressively to evade regulatory constraints. The loan-to-deposit ratio or LDR targets both sides of the balance sheet; loans in terms of asset-side, and deposits in terms of liabilitiesside; banks needed to control and maintain both sides. Regulators restricted Chinese banks to maintain a 75\% limit for their loan-depositratio. Banks' needed to either lower their loans or increase the deposits; WMPs helped banks to evade this limit. Banks issue more WMPs to control and manage a $75 \%$ statutory ceiling LDR. This WMPs-LDR positive association disappeared post-2015 period. This study empirically examined how Chinese banks use WMPs issuance to avoid regulatory constraints. Quarterly panel data for 30 top Chinese banks were used by analyzing pre-2015 (during the 75\% LDR limit) and post-2015 (after removal of the LDR limit). This study also performed fixed-effects model as recommended by the Hausman specification test, with feasible generalized least squares FGLS estimation technique. The results of this study show that for the pre-2015 period, Chinese banks use issuance of WMPs aggressively to manage their LDR limit; this WMPs-LDR relationship disappeared post-2015 period. Moreover, SMBs use WMPs more eagerly as compare to Big4 banks.
\end{abstract}

Keywords: Wealth Management Products, Shadow Banking, Loan-To-Deposit Ratio LDR, Regulations, Panel Data

JEL Classification Code: G21, G28, G32, C33

\section{Introduction}

The aftermath of the Global Financial Crisis GFC 20082009, shadow banking in China has been growing rapidly, mainly driven by regulatory arbitrage and the Chinese banking sector's response to the fiscal stimulus plan of 2008 . This sector has been enduring incremental growth despite the extensive regulations introduced by the regulatory authorities. Shadow banking in China is not contemplated as

${ }^{1}$ First Author and Corresponding Author. PhD Candidate, School of Finance, Central University of Finance and Economics, Beijing, China [Postal Address: 39 South College Road, Haidian, Beijing, 100000, China] Email: syed_mehmood1472@hotmail.com

${ }^{2}$ Dean, School of Finance, Central University of Finance and Economics, Beijing, China. Email: lijlsh@126.com

${ }^{3}$ Deputy of the Institute of Finance and Economics, Central University of Finance and Economics, Beijing, China.

Email: huaci_fuqiang@163.com

(c) Copyright: The Author(s)

This is an Open Access article distributed under the terms of the Creative Commons Attribution Non-Commercial License (https://creativecommons.org/licenses/by-nc/4.0/) which permits unrestricted non-commercial use, distribution, and reproduction in any medium, provided the original work is properly cited. a stigmatized phenomenon; instead, it helps fulfill the high demand for funding.

Unlike most western countries, China's financial sector is based on a strong banking system. Consequently, shadow banking is growing under the influence of the conventional banking system. Over a decade, in almost all the financial crunch situations, the rise of shadow banking is connected with the financing demands from various sectors of the economy (Z. Chen et al., 2020). After 2010, shadow banking grew at a swift pace; at the end of 2019, shadow banking assets reported as 59 trillion RMB, while in 2010, these assets were 17.3 trillion RMB (Moody's, 2020). For instance, wealth management products (WMPs), the most crucial component of Chinese shadow banking, as its nonguaranteed WMPs are totally off the balance sheet, grew more strongly.

The rise of shadow baking in China after 2008-2009 can be attributed to factors such as the stimulus plan launched in 2008 and regulatory arbitrage in terms of a 75\% limit on the loan-to-deposit ratio (LDR). The unweighted value of loans to the deposit ratio LDR is an essential financial indicator for banks' creditworthiness. The 1995 commercial banking law restricted Chinese banks to maintain their LDR below 
the $75 \%$ threshold. That rule was dismantled at the end of 2015. The LDR limit targets both sides of the balance sheet; loans in terms of the asset-side, and deposits in terms of the liabilities-side; banks needed to control and maintain both sides (loans \& deposits) pre-2015 period. At that time, banks needed to either lower their loans or increase the deposits; WMPs helped banks to achieve both these targets. Nonguaranteed WMPs helped banks to play freely outside the balance sheet, and principal-guaranteed WMPs helped banks to improve deposits.

In this study, we examine how Chinese banks use the issuance of WMPs as a tool to control and maintain a 75\% LDR limit (pre-2015), but this positive relationship disappeared post-2015 period. We also analyzed what other factors influenced the issuance of WMPs in addition to the LDR limit and how banks take advantage of regulatory arbitrage by relying on the WMPs. The sample of 30 top Chinese banks used in this study covers $70 \%$ of the total banking sector's assets. This study conducted panel data fixed effects models as an empirical investigation tool, and feasible generalized least squares (FGLS) technique was used for correcting heteroskedasticity and autocorrelation issues.

The results of this study show that Chinese banks rely heavily on WMPs, pre-2015 period for maintaining and controlling a $75 \%$ limit on the LDR, but this positive association disappeared post-2015 period. Other important conclusions drawn from this study were; for small \& mediumsized banks (SMBs), pre-2015 LDR-WMPs association was more significant than Big4 banks, along with other variables Spread (the difference between 3M WMPs yield and deposit rate) played an essential part in the issuance of WMPs.

This study contributes to the growing literature on shadow banking in China by providing pre \& post-2015 analysis for the LDR-WMPs association. This study is arranged as follows; the first section starts with an introduction, section 2 covers the existing literature, section 3 contains data and methodology, section 4 includes results and discussion; lastly, the conclusion is presented in section 5 .

\section{Literature Review}

In terms of China, three important types of shadow banking were explained by (The General Office of the State Council, 2013); Firstly, the institutions which are not well-regulated (e.g., finance companies related to internet business). Secondly, Intermediaries without proper financial service license (e.g., micro-finance and guarantee firms). Thirdly, fully regulated financial institutions but involved in under-rated or unregulated activities (e.g., conventional banks involved in WMPs, MMF, trust companies). As explained by (Gabrieli et al., 2018), the banking system in China is different from the US, as Chinese shadow banking is mostly dependent on well-regulated financial institutions, specifically commercial banks, and trust companies, while the US shadow banking sector is linked with formal capital markets.

(Banna et al., 2017) discussed that banks play a crucial role in bringing stability and economic development through their expected contribution in proper financial resource mobilization across the economy. (Li et al., 2014) while examining the institutional risks in China, explained that asset-backed securities or multipart financial instruments do not drive Chinese shadow banking. (Allen \& Gu, 2020) also corroborated that China's shadow banking sector has been growing very fast. The main driving forces were regulatory arbitrage and credit restrictions on specific industries; despite the continuous efforts by regulatory authorities to restrict the shadow banking activities, this sector kept growing.

Wealth management products are considered as a massive contributor to China's shadow banking system. These are deposit like products with fixed maturities, but not treated as deposits by regulatory authorities in China. Non-guaranteed WMPs are totally off the balance sheet and considered as shadow banking item. While principalguaranteed WMPs are on the balance sheet. (Wang et al., 2019) explained further that WMPs are helping in providing the social credit outside the well-regulated banking system, and these products are also connected with the interest rate liberalization process. Banks with higher profitability are proven to have lower credit quality issues (Rachman et al., 2018). China's banking sector use WMPs as a convenient tool for chasing profits and moving their toxic assets off the balance sheet (Wei, 2015). After 2010, Chinese shadow banking experienced a boom, mainly driven by regulatory arbitrage regarding restrictions on the on-balance sheet items. As argued by (Ha, 2019; Vuong et al., 2020) deposits play an important role in overall banking system. (Acharya et al., 2020) show that regulatory constraints such as loanto-deposit ratio LDR and capital adequacy ratio boosted this growth in shadow banking activities.

After the upsurge of the global financial crises of 2008-2009, the Chinese government initiated the RMB 4 trillion fiscal stimulus Plan in 2008. Consequently, banks started problems with their deposit levels. As LDR involves both the loan and deposit side of the balance sheet, for maintaining their LDRs below the $75 \%$ threshold, banks have two options, increase deposits or decrease loans. WMPs help banks to achieve both of these tasks.

The studies mentioned above show that after 2010, the rise of shadow banking in China resulted from the stimulus plan 2008, but most importantly, a 75\% limit on LDR, further helped the incremental growth in shadow banking activities. This literature has shown that shadow banking in China is deeply connected with the well-regulated commercial banks; and these banks use off-balance sheet activities such as the issuance of WMPs, by taking advantage of loopholes in the existing regulations. 


\section{Data and Empirical Methodology}

\subsection{Theoretical Framework}

In this study, we examined WMPs, the most critical component of Chinese shadow banking. As discussed earlier, the stimulus plan of 2008-2009, regulations in terms of liquidity management, and credit restrictions on some industries caused rapid growth in shadow banking in China. Similarly, Liquidity rules played an essential role in shaping the shadow banking sector, specifically the $75 \%$ limit on the loan to deposit ratio LDR (Hachem \& Song, 2017). Mostly the regulatory limitations are concerned with on-balance sheet items; this encouraged banks to use off the balance sheet activities to fulfill their intended goals. Our sample contains $78 \%$ of NG-WMPs of the total WMPs issued by the 30 Chinese banks; this confirms that Chinese banks rely heavily on non-guaranteed WMPs.

We hypothesize that the issuance of WMPs plays a significant role in helping Chinese banks to maintain and manage the $75 \%$ LDR limit pre- 2015 period; this relation remained more significant for SMBs, but this association disappeared post-2015 period. We also hypothesize that Spread (between 3-M WMPs yield and deposit rate) and profitability significantly affected the issuance of WMPs.

(Acharya et al., 2020) corroborated that during the financial crisis of 2008-2009, a 4 trillion RMB stimulus plan was initiated by the Chinese government. This plan was mainly executed by Big four banks, which caused trouble in maintaining the LDR below the $75 \%$ limit. Consequently, Big4 banks managed to raise the deposits to control their LDR limit. Conversely, SMBs found it challenging to manage their deposits; because of their lower number of branches, limited lending \& deposits businesses, and limitation in terms of specific regions. During the pre-2015 period, SMBs needed to increase their deposits net, especially to maintain their LDR under a $75 \%$ limit. These banks focused more on the issuance of WMPs, as WMPs have higher yields compared to the conventional deposit rates. The principal guaranteed WMPs was the best solution to raise their deposit levels, as they are on the balance sheet deposit-like products. At the same time, they found non-guaranteed WMPs helpful in terms of setting the maturity date around or before the quarter end, which enabled them to increase their deposits for a shorter period and control the LDR. We use pre-\&-post 2015 periods, as the $75 \%$ LDR limit was removed at the end of 2015.

A spread between the annualized yield of 3-month WMPs and deposit rate is another crucial factor in defining the WMPs for the Chinese banks. A greater spread between these two yields is considered as a positive signal to the investors. For the last decade, WMPs had helped Chinese banks to generate a large amount of profits (Wei, 2015). (Ramlan \& Adnan, 2016) examined empirically that return on equity ROE is the most suitable measure in terms of bank profitability. We use ROE as a basic measure for profitability, while ROA for robustness check. Other important variables are SHIBOR 3-month rate, and NPL ratio, we used the total revenue as a measure of bank size, as total revenue performs well compared to total assets and market capitalization.

\subsection{Empirical Design}

The effect of LDR and other variables on the issuance of NG-WMPs and total WMPs is estimated in terms of pre2015 and post 2015 periods. The panel regression models are as follows:

$$
\begin{aligned}
L\left(N G_{-} W M P\right)_{i t}= & \beta_{0}+\beta_{1} L D R_{i t}+\beta_{2} \text { Spread }_{t} \\
& +\beta_{3} \text { ROE }_{i t}+\beta_{4} \text { Shibor }_{t}+\beta_{5} \text { Size }_{i t} \\
& +\beta_{6} N P L_{i t}+\varepsilon_{i, t} \\
L\left(T_{-} W M P\right)_{i t}= & \beta_{0}+\beta_{1} L D R_{i t}+\beta_{2} \text { Spread }_{t}+\beta_{3} R O E_{i t}+ \\
& \beta_{4} \text { Shibor }_{t}+\beta_{5} \text { Size }_{i t}+\beta_{6} N P L_{i t}+\varepsilon_{i, t}
\end{aligned}
$$

Two dependent variables, NG-WMPs and total WMPs have been used in this study, $i$ represents the number of banks, $t$ and shows the quantity of time, $\varepsilon$ is the error term. $\beta_{1}$, $\beta_{2}, \beta_{3}, \beta_{4}, \beta_{5}$, and $\beta_{6}$ are coefficients of loan-to-deposit Ratio LDR, Spread, ROE, Shibor, Size, and NPLR, respectively. All the variables are log-transformed, the log transformation is considered as a good option for not only data normality but also it helps in staying away from the protentional sharpness in the data (Gabrieli et al., 2018).

\subsection{Empirical Procedure}

To pursue our discussed objectives, with quarterly data pre$\&$ post-2015, for 30 Chinese banks, this study use static panel models, as (Acharya et al., 2019; Cai et al., 2019; Liao, 2020; Luo et al., 2019; and Wu \& Shen, 2018) also implied static panel models (fixed effects, random effects, LSDV). Fixed effects and random effects models are the two most essential components of panel data. To determine between random effects and fixed effects estimators, this study performed (Hausman, 1978) test. The Hausman specification test probes the null hypothesis that "there is no correlation between the individual effects and regressors" if the null hypothesis is rejected, it would result in the rejection of the random-effects model.

As 75\% LDR limit was removed at the end of 2015, which is a well-known regulatory measure taken by the Chinese authorities, to confirm empirically further this well-defined structural break between the pre-\&-post 2015 periods, this study performed the Chow test as explained by (Gujarati \& Porter, 2009). For examining the issue of heteroskedasticity, this study performed two tests; White's test and modified 
Wald's test of group-wise heteroskedasticity, respectively. This study performed three tests to investigate the issue of autocorrelation. First, a (Wooldridge, 2002) test was performed, as implanted by (Drukker, 2003). Second, a panel data autocorrelation Breusch-Pagan-Godfrey test was executed. Lastly, the Durbin-Watson Test of auto-correlation was also performed. For examining cross-sectional dependence, this study performed (Breusch \& Pagan, 1980) test.

After performing all these diagnostic tests, and in the presence of heteroskedasticity, auto-correlation and crosssectional dependence, Feasible Generalized Least Squares (FGLS) is considered as a reliable and efficient solution. As investigated by (Moundigbaye et al., 2018; Reed \& Ye, 2011), the FGLS provides the appropriate corrections for non-stationarity, residual temporal and spatial dependence, heteroscedastic errors, and provides efficient coefficient estimates. (Bai et al., 2020) also explained that error variance is considered in the FGLS-estimation, which helps in minimizing the estimation bias. As (Wooldridge, 2013) further explained that FGLS corrects the errorvariance-structure by transforming the basic model. Lastly, a comprehensive set of data for 30 banks and ten years of quarterly data make the results of this study robust. We further examined the robustness by including ROA by replacing $\mathrm{ROE}$ as an alternate measure for banks' profitability.

\subsection{Data and Descriptive Statistics}

We utilized a diversified sample of 30 Chinese banks which include; Big4 or four large state-owned commercial banks, (JSCBs) 11 joint-stock commercial banks, (CCBs) 13 city commercial banks, and lastly (RCBs) 2 rural commercial banks; Appendix contains the details of all these banks. Other than Big four banks, we classify 26 banks as small \& medium size banks (SMBs). These thirty banks are the leading issuers of wealth management products; they also comprise $70 \%$ assets of China's banking system over the sample period from the first quarter of 2010 to the last quarter of 2019 . As the $75 \%$ LDR limit was removed in October 2015, we utilized two sub-samples; the pre-2015 sub-sample contains the data for the period before the last quarter of 2015 (from the first quarter of 2010 to the last quarter of 2015). In contrast, the post-2015 sub-sample contains the data after the last quarter of 2015 (from the first quarter of 2016 to the last quarter of 2019).

The data for this study was collected from multiple sources. For bank-related data, specifically financial ratios, we used the WIND financial database (a trusted and leading financial database in China). Additionally, we also used periodic financial statements and Bloomberg; these additional sources helped us not only to overcome the missing observations but also in validating the data. Lastly, for each bank in our sample, we collected non-guaranteed WMPs and total WMPs (includes both NG-WMPs \& Guaranteed-WMPs) from the WIND database, which includes issuing bank details, issuing date of WMP, yield and its type, maturity duration, assets attached with WMPs. We use the number of WMPs as the proxy for the bank's exposure to these financial products, as there is no information available for individual bank-issued WMP's amount. As (Cai et al., 2019; Luo et al., 2019) use the number of WMPs as a measure for banks' exposure to this business. Our sample contains 315,894 NG- WMPs and 403,036 total WMPs. Figure 1 depicts NG-WMPs and T-WMPs over time.

Table 1 Reports the descriptive statistics, in terms of pre\&-post 2015 periods, respectively. In all the panels, greater average values of bank-issued NG-WMPs shows that these products are the leading contributors in the total number of WMPs, which is $78 \%$ of total WMPs. For the LDR, Pre-2015 period, the average LDR was reported $65.77 \%$, which is below the $75 \%$ cap by the authorities. However, for the Post2015 period, the average LDR is $76.24 \%$, which indicates that after the removal of the $75 \%$ restriction, banks' LDR ratios increased. An increasing trend can also be seen in the Spread, pre-\&-post 2015, it has values of 1.74 and 2.89 , respectively.

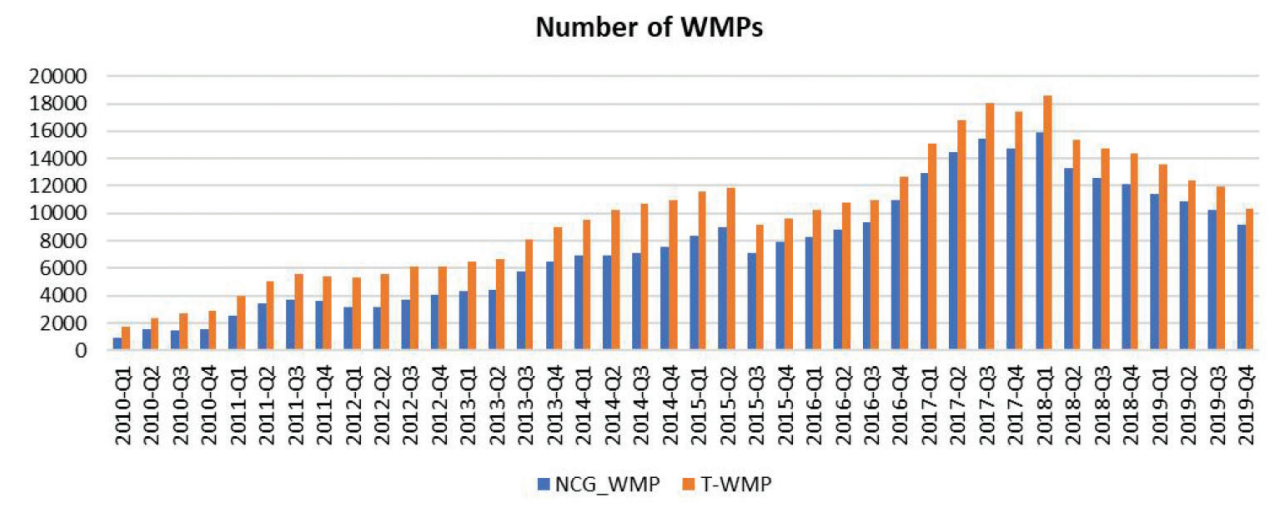

Figure 1: Non-guaranteed and total WMPs overtime

Source: Calculated and depicted by authors, by using data from WIND database 
Table 1: Descriptive Statistics

\begin{tabular}{|l|c|c|c|c|c|c|c|c|c|c|c|c|}
\hline \multirow{2}{*}{ Variables } & \multicolumn{9}{|c|}{ (Pre-2015) } & \multicolumn{5}{c|}{ (Post-2015) } \\
\cline { 2 - 14 } & Obs. & Mean & SD & min & Median & max & Obs. & Mean & SD & min & Median & max \\
\hline NG-WMPs & 720 & 159.619 & 234.43 & 0 & 81.5 & 2355 & 480 & 397.221 & 580.579 & 0 & 165.5 & 3789 \\
\hline T-WMPs & 720 & 231.808 & 312.299 & 0 & 117 & 2559 & 480 & 465.385 & 606.32 & 0 & 227.5 & 3892 \\
\hline LDR & 720 & 65.779 & 7.802 & 35.925 & 67.877 & 83.347 & 480 & 76.244 & 12.475 & 46.46 & 75.351 & 110.992 \\
\hline Spread & 720 & 1.741 & .89 & .003 & 1.74 & 4.476 & 480 & 2.897 & .491 & 1.494 & 2.878 & 4.658 \\
\hline ROE & 720 & 19.591 & 3.827 & 6.864 & 19.385 & 34.786 & 480 & 13.694 & 3.082 & 4.513 & 13.558 & 28.82 \\
\hline ROA & 720 & 1.185 & .222 & .404 & 1.18 & 1.852 & 480 & .943 & .188 & .37 & .932 & 1.506 \\
\hline NPL ratio & 720 & .943 & .369 & .11 & .92 & 2.46 & 480 & 1.556 & .401 & .78 & 1.545 & 3.82 \\
\hline T-Rev M & 720 & 59856.61 & 110000 & 960.573 & 11546.36 & 697647 & 480 & 89089.97 & 146000 & 829.735 & 24553.93 & 855164 \\
\hline Assets M & 720 & 3070000 & 4920000 & 36496.3 & 669000 & $2.24 \mathrm{e}+07$ & 480 & 5150000 & 7360000 & 112674 & 1706355 & $3.04 \mathrm{e}+07$ \\
\hline
\end{tabular}

\section{Results and Discussion}

This section shows the results of our two main equations, 1 and 2. Non-guaranteed WMPs and total WMPs are the two dependent variables. For both the estimated equations, we use variables measured at the end of each quarter. For panel data, pooling the data and running the single regression on all the cross-sections for a given period would be an effortless estimation technique. However, for pooling the data, do not ignores the heterogeneity, which is not appropriate, as this study has panel data with a significant number of crosssections and observations. From a theoretical aspect, the fixed effects model would be the right choice for considerable large periods and cross-sectional data. We performed an F-test, between the pooled model and the fixed effects model, to examine which model is suitable. The Hausman test also preferred the fixed effects model over the randomeffects model.

As discussed earlier, a $75 \%$ limit on the LDR by the regulatory authorities is a well-known event in the history of the Chinese regulatory system. To further confirm this well-defined structural break between the pre-\&-post 2015 empirically, this study performed a Chow test. The estimated value of the Chow test statistic equaled 19.85 and exceeded the corresponding critical value of the F-distribution at a $1 \%$ level of significance (2.64). The Chow test, therefore, seems to support that the LDR-WMPs relation has undergone a structural change over the period 2010 to 2019.

We cannot report and discuss the results from the fixed-effects model, as some diagnostic tests need to be performed for the presence of heteroskedasticity, autocorrelation, and cross-sectional dependence. These tests would determine the reliability of the fixed-effects model. We use two tests for heteroskedasticity. The White's test and Modified Wald test were found significant at 1\% level and rejected the null hypothesis of "homoskedasticity." For auto-correlation; Wooldridge test for auto-correlation, panel data auto-correlation Breusch-Pagan-Godfrey test, and the Durbin-Watson test of auto-correlation. The null hypothesis of "no AR (1) panel auto-correlation" was rejected at a $1 \%$ level for all the three tests. For cross-sectional dependence in residuals, a Breusch-Pagan LM test was executed after the fixed effects model. The null hypothesis of "CrossSectional Independence" was rejected at a significance level of $1 \%$. Which make the results of the fixed-effects model biased. As (Moundigbaye et al., 2018; Reed \& Ye, 2011) concluded that FGLS-Parks estimator is considered as the best solution for auto-correlation, heteroskedasticity, non-stationary series, and cross-sectional dependence. This study performed equations 1 and 2 by estimating the FGLSFE estimator.

For FGLS-FE, results are presented in panels A and B of Table 2 and Table 3, respectively. Table 2, panel A and $\mathrm{B}$ contain the results for non-guaranteed WMPs and total WMPs for all 30 sample banks; in terms of pre-\&-post 2015 periods, all three FGLS models have robust results. For NG-WMPs and total WMPs, the LDR is positive and significant for the pre-2015 period, but this positive and significant relation disappeared in the post-2015 subsample. As the pre-2015 period had the limit on LDR, which prohibited the banks from lending more than $75 \%$ of their total deposits. To manage this LDR threshold, banks need to increase the deposits or decrease total loans. During the pre-2015 period, WMPs helped banks to achieve both these tasks. Using the coefficients on LDR in column 3 (pre-2015 period), we can interpret that a $1 \%$ increase in the LDR led to an increase in the issuance of NG-WMPs by $0.17 \%$. 
Table 2: FGLS-FE, All banks (Pre \& Post 2015)

\begin{tabular}{|c|c|c|c|c|c|c|c|c|c|c|c|c|}
\hline \multirow{2}{*}{ Variables } & \multicolumn{3}{|c|}{$\begin{array}{c}\text { Non-Guaranteed-WMPs } \\
\text { (Pre-2015) }\end{array}$} & \multicolumn{3}{|c|}{$\begin{array}{c}\text { Non-Guaranteed-WMPs } \\
\text { (Post-2015) }\end{array}$} & \multicolumn{3}{|c|}{$\begin{array}{l}\text { Total-WMPs } \\
\text { (Pre-2015) }\end{array}$} & \multicolumn{3}{|c|}{$\begin{array}{l}\text { Total-WMPs } \\
\text { (Post- 2015) }\end{array}$} \\
\hline & (1) & (2) & (3) & (1) & (2) & (3) & (1) & (2) & (3) & (1) & (2) & (3) \\
\hline \multirow[t]{2}{*}{ LDR } & $0.141^{* *}$ & $0.145^{\star \star}$ & $0.175^{* * *}$ & -0.002 & 0.002 & -0.007 & $0.117^{* * *}$ & $0.078^{*}$ & $0.123^{* * *}$ & -0.027 & -0.022 & -0.030 \\
\hline & $(0.059)$ & $(0.066)$ & $(0.060)$ & $(0.045)$ & $(0.045)$ & $(0.045)$ & $(0.043)$ & $(0.041)$ & $0.042)$ & $(0.041)$ & $(0.041)$ & $(0.041)$ \\
\hline \multirow[t]{2}{*}{ Spread } & $0.374^{* * *}$ & $0.306^{* * *}$ & $0.341^{* * *}$ & $0.135^{* *}$ & 0.115 & $0.136^{*}$ & $0.158^{* * *}$ & $0.129^{* * *}$ & $0.128^{* * *}$ & $0.143^{* *}$ & $0.120^{*}$ & $0.149^{* *}$ \\
\hline & $(0.042)$ & $(0.046)$ & $(0.042)$ & $(0.068)$ & $(0.070)$ & $(0.069)$ & $(0.034)$ & $(0.036)$ & $(0.034)$ & $(0.064)$ & $(0.064)$ & $(0.066)$ \\
\hline \multirow[t]{2}{*}{ ROE } & $0.288^{* * *}$ & $0.320^{* * *}$ & $0.353^{* * *}$ & $0.125^{\star * \star}$ & $0.087^{* * *}$ & $0.129^{* \star *}$ & $0.247^{\text {***}}$ & $0.192^{* * *}$ & $0.290^{\star * *}$ & $0.105^{\star \star \star}$ & $0.076^{\star \star}$ & $0.117^{* * *}$ \\
\hline & $(0.052)$ & $(0.059)$ & $(0.054)$ & $(0.033)$ & $(0.031)$ & $(0.034)$ & $(0.044)$ & $(0.046)$ & $(0.045)$ & $(0.034)$ & $(0.031)$ & $(0.035)$ \\
\hline \multirow[t]{2}{*}{ SHIBOR } & $0.184^{* * *}$ & $0.208^{* * *}$ & $0.221^{* \star *}$ & $0.071^{* *}$ & $0.054^{*}$ & $0.071^{* *}$ & $0.148^{* * *}$ & $0.156^{* * \star}$ & $0.189^{\star \star *}$ & 0.032 & 0.021 & 0.033 \\
\hline & $(0.034)$ & $(0.0$ & $(0.035)$ & $(0.029)$ & $(0$ & $(0.029)$ & $(0.027)$ & $(0$ & $(0.028)$ & $(0.027)$ & 7) & $(0.028)$ \\
\hline \multirow[t]{2}{*}{ Size } & $0.546^{* * *}$ & & $0.504^{* * *}$ & $0.102^{* * *}$ & & $0.102^{* \star *}$ & $0.422^{* * *}$ & & $0.390^{* * *}$ & $0.072^{* *}$ & & $0.088^{* * *}$ \\
\hline & $(0.043)$ & & $(0.044)$ & $(0.036)$ & & $(0.036)$ & $(0.035)$ & & $(0.036)$ & $(0.033)$ & & $(0.034)$ \\
\hline \multirow[t]{2}{*}{ NPLR } & & $0.370^{* * *}$ & $0.263^{* * *}$ & & . & 0.082 & & $0.321^{* * *}$ & $0.304^{* * *}$ & & 0.000 & 0.024 \\
\hline & & $(0.080)$ & $(0.066)$ & & $(0.079)$ & $(0.078)$ & & $(0.068)$ & $(0.058)$ & & $(0.074)$ & $(0.073)$ \\
\hline \multirow[t]{2}{*}{ Cons. } & $4.390^{* \star *}$ & $4.421^{* * *}$ & $4.448^{\star * *}$ & $5.192^{\star * \star}$ & $5.139^{* \star *}$ & $5.159^{* \star *}$ & $4.822^{\star \star \star}$ & $4.867^{* * \star}$ & $4.860^{* * *}$ & $5.392^{\star \star \star}$ & $5.374^{* * *}$ & $5.383^{* \star \star}$ \\
\hline & $(0.064)$ & $(0.087)$ & $(0.065)$ & $(0.110)$ & $(0.116)$ & $(0.117)$ & $(0.060)$ & $(0.079)$ & $(0.062)$ & $(0.100)$ & $(0.107)$ & $(0.101)$ \\
\hline Obs. & 720 & 720 & 720 & 480 & 480 & 480 & 720 & 720 & 720 & 480 & 480 & 480 \\
\hline Wald-Chi ${ }^{2}$ & $370.24^{* * *}$ & $143.33^{* \star \star}$ & $387.15^{\star \star \star}$ & $29.27^{* * *}$ & $20.16^{\star * *}$ & $29.81^{\text {***}}$ & $243.86^{\star * *}$ & $82.56^{\star * *}$ & $260.55^{* \star \star}$ & $18.94^{* * \star}$ & $14.13^{\star \star \star}$ & $21.42^{* * \star}$ \\
\hline
\end{tabular}

The models control for common auto-regressive parameter and panel level heteroscedasticity. Bank and quarter fixed effects are included in all the models Coefficients with standard errors are in parenthesis. ${ }^{* *} p<0.01,{ }^{* *} p<0.05,{ }^{*} p<0.1$

Table 3 panels A \& B further summarized the empirical results for SMBs (small \& medium-size banks) in terms of NG-WMPs and total WMPs. In the pre-2015 period, LDR was positive and significant for all three FLGS models, but this significant association disappeared for the post2015 period. In term of non-guaranteed WMPs, using the coefficients on LDR in column 3 (pre-2015 period), we can interpret that a $1 \%$ increase in the LDR led to an increase in the issuance of NG-WMPs by $0.14 \%$. These findings prove our earlier argument that SMBs have fewer branches and their business (lending $\&$ deposits) are limited to specific regions; these limitations make the issuance of WMPs a rewarding option for SMBs, which helped them in the pre-2015 period to stay below the $75 \%$ LDR limit. Moreover, our unreported results for Big 4 banks also show that SMBs use WMPs more aggressively prior 2015 period as compared to Big 4 banks. It is worth mentioning that the stimulus plan launched in 2008, and it was implanted mostly by Big 4 banks, which enabled them to increase their lending activities; although Big 4 banks' WMPs issuance also experienced increasing trend, we can argue that Big 4 banks' WMPs rose as a response to WMPs issuance by the SMBs. Our results are consistent with (Acharya et al., 2019; Cai et al., 2019).
The results for Spread (between 3-M WMPs yield and deposit rate) are presented in panels A and B of Table 2 \& Table 3, for all banks and SMBs, respectively. In both pre-\&post 2015 periods, spread played a vital role in the issuance of WMPs for all banks and more prominently for SMBs. Greater the spread, the banks would issue more WMPs. More specifically, the coefficients of spread after the 2015 period are not significant in column (2) for both NG-WMPs and total WMPs; other columns also have lower significance levels, in terms of economic magnitude 1\% increase in the Spread between WMP yield and deposit rate led to an increase in the issuance of NG-WMPs by $0.34 \%$. As for other variables, empirical outcomes of Table $2 \&$ Table 3, panels A and B, for both pre and post-2015 periods, shows that issuance of both NG-WMPs and total WMPs are positively and significantly related to the profitability, which shows that the Chinese banking industry's tendency to chase profits has a significant impact on WMPs issuance in pre and post 2015. Similar results were found by (Wu \& Shen, 2018). SHIBOR-3M and NPLR were positive and significant pre-2015 period, but the majority of their coefficients were found to be not significant in the post-2015 periods for all banks and SMBs as well. These discoveries are in line with (Acharya et al., 2019; Cai et al., 2019; Liao, 2020; Luo et al., 2019). 
Table 3: FGLS-FE Small \& medium size (SMBs) banks

\begin{tabular}{|c|c|c|c|c|c|c|c|c|c|c|c|c|}
\hline \multirow{2}{*}{ Variables } & \multicolumn{3}{|c|}{\begin{tabular}{|c|}
$\begin{array}{c}\text { Non-Guaranteed-WMPs } \\
\text { (Pre-2015) }\end{array}$ \\
\end{tabular}} & \multicolumn{3}{|c|}{$\begin{array}{c}\text { Non-Guaranteed-WMPs } \\
\text { (Post-2015) }\end{array}$} & \multicolumn{3}{|c|}{$\begin{array}{l}\text { Total-WMPs } \\
\text { (Pre-2015) }\end{array}$} & \multicolumn{3}{|c|}{$\begin{array}{l}\text { Total-WMPs } \\
\text { (Post- 2015) }\end{array}$} \\
\hline & (1) & (2) & (3) & (1) & (2) & (3) & (1) & (2) & (3) & (1) & (2) & (3) \\
\hline \multirow[t]{2}{*}{ LDR } & $0.118^{*}$ & $0.115^{*}$ & $0.140^{* *}$ & \begin{tabular}{|c|}
-0.021 \\
\end{tabular} & -0.015 & -0.026 & $0.119^{* *}$ & $0.090^{* *}$ & $0.107^{* *}$ & -0.041 & -0.036 & -0.043 \\
\hline & $(0.061)$ & $(0.068)$ & $(0.062)$ & (0.049) & $(0.049)$ & \begin{tabular}{|l|}
$(0.049)$ \\
\end{tabular} & $(0.047)$ & $(0.044)$ & $043)$ & $(0.043)$ & $(0.043)$ & $(0.044)$ \\
\hline \multirow[t]{2}{*}{ Spread } & $0.403^{* * *}$ & $0.326^{* * *}$ & $0.337^{* * *}$ & $0.141^{*}$ & 0.124 & $0.139^{*}$ & $0.163^{* * *}$ & $0.130^{* * *}$ & $0.101^{* * *}$ & $0.127^{*}$ & 0.105 & $0.127^{*}$ \\
\hline & $(0.046)$ & $(0.049)$ & \begin{tabular}{|l|}
$(0.047)$ \\
\end{tabular} & $(0.077)$ & $(0.078)$ & \begin{tabular}{|l|}
$(0.077)$ \\
\end{tabular} & $(0.038)$ & $(0.040)$ & $(0.038)$ & \begin{tabular}{|l|}
$(0.069)$ \\
\end{tabular} & $(0.067)$ & $(0.069)$ \\
\hline \multirow[t]{2}{*}{ ROE } & $0.259^{* * *}$ & $0.323^{* * *}$ & $0.360^{\star \star *}$ & $0.115^{\star \star \star}$ & $0.090^{* \star *}$ & $0.119^{\star \star \star}$ & $0.227^{\star \star *}$ & $0.209^{* * *}$ & $0.312^{* * *}$ & $0.092^{* * *}$ & $0.070^{* *}$ & $0.095^{\star \star *}$ \\
\hline & (0.055) & $(0.062)$ & $(0.058)$ & (0.034) & $(0.032)$ & $(0.035)$ & $(0.048)$ & (0.049) & $(0.049)$ & $(0.035)$ & $(0.032)$ & $(0.035)$ \\
\hline \multirow[t]{2}{*}{ SHIBOR } & $0.146^{* * *}$ & $0.183^{* * *}$ & $0.197^{\star \star *}$ & $0.055^{*}$ & 0.043 & $0.055^{*}$ & $0.131^{* * *}$ & $0.151^{* * *}$ & $0.192^{* * *}$ & 0.020 & 0.014 & 0.021 \\
\hline & $(0.037)$ & $(0.039)$ & $(0.038)$ & (0.032) & $(0.032)$ & $(0.032)$ & $(0.030)$ & $(0.03$ & $(0.031)$ & \begin{tabular}{|l|}
$(0.029)$ \\
\end{tabular} & 8) & $(0.029)$ \\
\hline \multirow[t]{2}{*}{ Size } & $0.563^{* * *}$ & & $0.543^{* * *}$ & $0.078^{* *}$ & & $0.077^{*}$ & $0.491^{\text {***}}$ & & $0.475^{\star * *}$ & 0.056 & & 0.057 \\
\hline & $(0.054)$ & & $(0.053)$ & (0.040) & & $(0.040)$ & $(0.045)$ & & $(0.044)$ & $(0.036)$ & & $(0.036)$ \\
\hline \multirow[t]{2}{*}{ NPLR } & & $0.343^{* * *}$ & $0.323^{* \star *}$ & & 0.000 & 0.086 & & $0.351^{* * *}$ & $0.409^{* * *}$ & & 0.040 & 0.031 \\
\hline & & $(0.088)$ & $(0.072)$ & & $(0.085)$ & $(0.085)$ & & $(0.074)$ & (0.062) & & $(0.077)$ & $(0.076)$ \\
\hline \multirow[t]{2}{*}{ Cons. } & $4.356^{* \star *}$ & $4.267^{* \star *}$ & $4.458^{\star \star \star}$ & $5.014^{\star \star \star}$ & $4.953^{\star \star *}$ & $4.987^{* * *}$ & $4.754^{\star * *}$ & $4.711^{\star * *}$ & $4.863^{* * *}$ & $5.254^{* * *}$ & $5.230^{* * *}$ & $5.240^{* \star *}$ \\
\hline & \begin{tabular}{|l|}
$(0.066)$ \\
\end{tabular} & $(0.091)$ & $\begin{array}{l}(0.069) \\
\end{array}$ & (0.122) & $(0.124)$ & $(0.129)$ & $(0.059)$ & (0.079) & $(0.062)$ & $(0.107)$ & $(0.119)$ & $(0.112)$ \\
\hline Obs. & 624 & 624 & 624 & 416 & 416 & 416 & 624 & 624 & 624 & 416 & 416 & 416 \\
\hline Wald-Chi2 & $308.77^{\star * *}$ & $125.79^{\star * \star}$ & $335.72^{\star * \star}$ & $21.10^{\star \star *}$ & $16.77^{* * *}$ & $21.57^{\star \star \star}$ & $220.58^{\star * *}$ & $75.64^{\star \star *}$ & $261.91^{* * *}$ & $13.04^{* * *}$ & $10.71^{* *}$ & $13.27^{\star *}$ \\
\hline
\end{tabular}

The models control for common auto-regressive parameter and panel level heteroscedasticity. Bank and quarter fixed effects are included in all the models Coefficients with standard errors are in parenthesis. ${ }^{* *} p<0.01,{ }^{* *} p<0.05,{ }^{*} p<0.1$

This study implemented an alternate measure for ROE (return on equity) by replacing it with ROA (return on assets). The unreported results are in line with our reported results. Even in the extended model with ROA, the LDR is positively significant for pre-2015, but this positive association disappeared for the post-2015 period. All other variables showed similar significant levels as they did in previous models.

\section{Conclusion}

This study investigated the most crucial component of the Chinese shadow banking sector, i.e., wealth management products, by analyzing their relationship with regulatory constraint in terms of a $75 \%$ limit on the LDR. The majority of these bank-issued products are non-guaranteed and off the balance sheet, having these attributes make them more toxic for overall financial stability.

This study confirmed that Chinese banks use WMPs as a tool to evade the $75 \%$ limit on the LDR, i.e., pre2015 period. The estimated results of this study show that Chinese banks' issuance of WMPs significantly contributed to regulatory arbitrage. Interestingly, this WMPs-LDR positive association disappeared after the removal of the
LDR limit at the end of 2015. This study further revealed that small \& medium-sized banks use WMPs more aggressively than Big 4 banks to stay below the $75 \%$ LDR threshold. Moreover, results confirm that the issuance of WMPs are also significantly associated with Spread (between 3-month WMPs yield and deposit rate) and profitability. The findings of this study have confirmed that the Chinese banking sector relies heavily on WMPs.

\section{References}

Acharya, V. V., Qian, J., Su, Y., \& Yang, Z. (2019). In the Shadow of Banks: Wealth Management Products and Issuing Banks' Risk in China. https://www.ssrn.com/abstract=3401597

Acharya, V. V., Qian, J., Su, Y., \& Yang, Z. (2020). In the Shadow of Banks: Wealth Management Products and Issuing Banks' Risk in China. SSRN Scholarly Paper ID 3401597. Social Science Research Network. https://doi.org/10.2139/ssrn.3401597

Allen, F., \& Gu, X. (2020). Shadow banking in China compared to other countries. The Manchester School, 13. https://doi. org/10.1111/manc.12331

Bai, J., Choi, S. H., \& Liao, Y. (2020). Feasible Generalized Least Squares for Panel Data with Cross-sectional and Serial Correlations. ArXiv:1910.09004 [Econ]. http://arxiv.org/abs/1910.09004 
Banna, H., Ahmad, R., \& Koh, E. H. Y. (2017). Determinants of Commercial Banks' Efficiency in Bangladesh: Does Crisis Matter? Journal of Asian Finance, Economics and Business, 4(3), 19-26. https://doi.org/10.13106/jafeb.2017. vol4.no3.19

Breusch, T. S., \& Pagan, A. (1980). The Lagrange Multiplier Test and its Applications to Model Specification in Econometrics. Review of Economic Studies, 47(1), 239-253. https:// econpapers.repec.org/article/ouprestud/v_3a47_3ay_3a1980_ 3ai_3a1_3ap_3a239-253..htm

Cai, J., García-Herrero, A., Li, F., \& Le, X. (2019). The regulatory arbitrage and window dressing in shadow banking: The example of Chinese wealth management product. Economic and Political Studies, 7(3), 314-336. https://doi.org/10.1080/2 0954816.2019 .1633825

Chen, K., Ren, J., \& Zha, T. (2018). The Nexus of Monetary Policy and Shadow Banking in China. American Economic Review, 108(12), 3891-3936. https://doi.org/10.1257/aer.20170133

Chen, Z., He, Z., \& Liu, C. (2020). The financing of local government in China: Stimulus loan wanes and shadow banking waxes. Journal of Financial Economics, 137(1), 42-71. https:// doi.org/10.1016/j.jfineco.2019.07.009

Drukker, D. M. (2003). Testing for serial correlation in linear paneldata models. Stata Journal, 3(2), 168-177. https://econpapers. repec.org/article/tsjstataj/v_3a3_3ay_3a2003_3ai_3a2_3ap_ 3a168-177.htm

Gabrieli, T., Pilbeam, K., \& Shi, B. (2018). The impact of shadow banking on the implementation of Chinese monetary policy. International Economics and Economic Policy, 15(2), 429-447. https://doi.org/10.1007/s10368-017-0397-z

Gujarati, D. N., \& Porter, D. C. (2009). Basic econometrics (5th ed). New York, NY: McGraw-Hill Irwin.

Ha, V. D. (2019). Do Long Term Savings Motives Foster Household Participation and Contribution to Savings Mechanisms in Rural Vietnam? Journal of Asian Finance, Economics and Business, 6(2), 75-82. https://doi.org/10.13106/jafeb.2019. vol6.no2.75

Hachem, K., \& Song, Z. M. (2017). Liquidity Regulation and Credit Booms: Theory and Evidence from China (p. 71) [Working Paper]. Chicago Booth.

Hausman, J. A. (1978). Specification tests in econometrics. Econometrica: Journal of the Econometric Society, 1251-1271.

Kang, S., Lee, W. S., Moon, J., \& Kim, W. G. (2019). The influence of leisure and travel experiences on the school enjoyment of adolescents: A panel analysis. Leisure Studies, 38(4), 548-557. https://doi.org/10.1080/02614367.2019.1586980

Li, J., Hsu, S., \& Qin, Y. (2014). Shadow banking in China: Institutional risks. China Economic Review, 31, 119-129. https://doi.org/10.1016/j.chieco.2014.08.003

Liao, P. (2020). Interaction between Non-standard Debt and Wealth Management Products in China. Journal of Applied Finance and Banking, 10(5), 149-166.
Luo, R., Fang, H., Liu, J., \& Zhao, S. (2019). Maturity mismatch and incentives: Evidence from bank issued wealth management products in China. Journal of Banking \& Finance, 107, 105615. https://doi.org/10.1016/j.jbankfin.2019.105615

Miller, S. R., \& Startz, R. (2018). Feasible Generalized Least Squares Using Machine Learning. https://doi.org/10.2139/ ssrn.2966194

Moody's (Quarterly China Shadow Banking Monitor, p. 45). (2020). Moody's Investor Service. https://www.moodys.com/ researchdocumentcontentpage.aspx?docid=PBC_1220469

Moundigbaye, M., Rea, W. S., \& Reed, W. R. (2018). Which panel data estimator should I use?: A corrigendum and extension. Economics: The Open-Access, Open-Assessment E-Journal. https://doi.org/10.5018/economics-ejournal.ja.2018-4

Rachman, R. A., Kadarusman, Y. B., Anggriono, K., \& Setiadi, R. (2018). Bank-specific Factors Affecting Non-performing Loans in Developing Countries: Case Study of Indonesia. Journal of Asian Finance, Economics and Business, 5(2), 35-42. https:// doi.org/10.13106/jafeb.2018.vol5.no2.35

Ramlan, H., \& Adnan, M. S. (2016). The profitability of Islamic and conventional bank: Case study in Malaysia. Procedia Economics and Finance, 35, 359-367.

Reed, W. R., \& Ye, H. (2011). Which panel data estimator should I use? Applied Economics, 43(8), 985-1000. https://doi. org/10.1080/00036840802600087

Tan, Y. (2017). The impacts of competition and shadow banking on profitability: Evidence from the Chinese banking industry. The North American Journal of Economics and Finance, 42, 89-106. https://doi.org/10.1016/j.najef.2017.07.007

The General Office of the State Council. (2013). Notice of the General Office of the State Council on Issues concerning Strengthening the Supervision of Shadow Banking. http:// en.pkulaw.cn/display.aspx?cgid=264165\&lib=law

Vuong, B. N., Tung, D. D., Giao, H. N. K., Dat, N. T., \& Quan, T. N. (2020). Factors Affecting Savings Deposit Decision of Individual Customers: Empirical Evidence from Vietnamese Commercial Banks. Journal of Asian Finance, Economics and Business, 7(7), 293-302. https://doi.org/10.13106/jafeb.2020. vol7.no7.293

Wang, H., Wang, H., Wang, L., \& Zhou, H. (2019). Shadow Banking: China's Dual-Track Interest Rate Liberalization (SSRN Scholarly Paper ID 2606081). Social Science Research Network. https://doi.org/10.2139/ssrn.2606081

Wei, S. (2015). Wealth Management Products in the Context of China's Shadow Banking: Systemic Risks, Consumer Protection and Regulatory Instruments. Asia Pacific Law Review, 23(1), 91-123. https://doi.org/10.1080/10192557.2015.11745931

Wooldridge, J. M. (2002). Econometric analysis of cross section and panel data. Cambridge, MA: MIT Press.

Wooldridge, J. M. (2013). Introductory econometrics: A modern approach (5th ed). Boston, MA: South-Western Cengage Learning. 
Wu, M. W., \& Shen, C. H. (2018). Effects of shadow banking on bank risks from the view of capital adequacy. International Review of Economics \& Finance. https://doi.org/10.1016/j. iref.2018.09.004
Yang, L., van Wijnbergen, S., Qi, X., \& Yi, Y. (2019). Chinese shadow banking, financial regulation and effectiveness of monetary policy. Pacific-Basin Finance Journal, 57, 101169. https://doi.org/10.1016/j.pacfin.2019.06.016 
Appendix: List of banks

\begin{tabular}{|c|c|c|}
\hline & Bank names & Bank type \\
\hline 1 & $\begin{array}{l}\text { Agricultural Bank of China; Industrial and Commercial Bank of China; Bank of China; China } \\
\text { Construction Bank }\end{array}$ & State-owned Big Four \\
\hline 2 & $\begin{array}{l}\text { Bank of Communications; China Bohai Bank; China Zheshang Bank; Hua Xia Bank; China CITIC } \\
\text { Bank; Shanghai Pudong Development Bank; China Everbright Bank; China Merchants Bank; } \\
\text { China Minsheng Banking; Industrial Bank; Ping-An Bank }\end{array}$ & $\begin{array}{l}11 \text { - Joint-stock commercial } \\
\text { banks }\end{array}$ \\
\hline 3 & $\begin{array}{l}\text { Bank of Beijing; Bank of Chongqing; Bank of Dongguan; Bank of Hangzhou; Bank of Hebei; Bank } \\
\text { of Nanjing; Bank of Ningbo Bank of Ningxia; Bank of Shanghai; Bank of Tianjin; Harbin Bank; } \\
\text { Zhejiang Chouzhou Commercial Bank; Hankou Bank HKB }\end{array}$ & 13-City commercial banks \\
\hline 4 & Guangzhou Rural Commercial Bank; Shanghai Rural Commercial Bank & 02- Rural commercial banks \\
\hline
\end{tabular}

